\title{
Dosage escalation of intravesical oxybutynin in the treatment of neurogenic bladder patients
}

\author{
A Haferkamp*,1, G Staehler ${ }^{1}$, HJ Gerner ${ }^{2}$ and J Dörsam ${ }^{1}$ \\ ${ }^{1}$ Department of Urology, University of Heidelberg, Heidelberg, Germany; ${ }^{2}$ Department of Orthopedic Surgery and \\ Rehabilitation Medicine, University of Heidelberg, Heidelberg, Germany
}

\begin{abstract}
Objective: We prospectively analyzed the dose dependent outcome and side effects of neurogenic bladder patients with intravesical application of oxybutynin at our centre.

Materials and methods: We examined the data of 32 patients with neurogenic bladders and detrusor hyperreflexia. We registered clinical outcome, continence situation, side effects and urodynamic data of patients with (A) standard dosages of intravesical oxybutynin $(0.3 \mathrm{mg} / \mathrm{kg}$ bodyweight per day) and (B) with increasing dosages in steps of $0.2 \mathrm{mg} / \mathrm{kg}$ bodyweight per day up to $0.9 \mathrm{mg} / \mathrm{kg}$ bodyweight per day.

Results: We examined 32 patients aged 1 to 34 years, mean age 12 years. 21/32 patients became totally continent with the dosage (A). They showed a significant $(P<0.01)$ decrease in the median max detrusor pressure (MDP) and a significant $(P<0.01)$ increase in the median compliance and the median age adjusted bladder capacity (AABC). Eleven out of 32 patients remained incontinent under this dosage (A). Their median MDP, their median compliance and their median AABC remained nearly unchanged. Seven out of 11 incontinent patients under dosage (A) were treated efficiently with the higher dosages (B). Their median necessary dosage escalation to achieve treatment success was $0.7 \mathrm{mg} / \mathrm{kg}$ bodyweight per day (range 0.5 to $0.9 \mathrm{mg} / \mathrm{kg}$ bodyweight per day). Their median MDP was significantly $(P<0.05)$ decreased and their median compliance and median AABC were significantly $(P<0.05)$ increased. Four out of 11 patients remained incontinent and showed only little improvement in urodynamic data. Two out of 11 patients with the dosage escalation (B) showed side effects at a dosage of $0.9 \mathrm{mg} / \mathrm{kg}$ bodyweight per day.

Conclusions: The intravesical application of oxybutynin was a well tolerated and efficacious therapy. The topical oxybutynin therapy dosage (A) was efficient in $66 \%$ of our selected patients, the escalating dosage titration (B) could increase the efficiency to $87 \%$.

Spinal Cord (2000) 38, 250-254
\end{abstract}

Keywords: anticholinergics; neurogenic bladder; urodynamics

\section{Introduction}

The clinical management of neurogenic bladder dysfunction has dramatically improved since Guttmann et $a l^{1}$ and Lapides et $a l^{2}$ introduced the intermittent catheterization. McGuire et $a l^{3}$ recognized in 1981 that low storage pressures of the bladder protected the upper urinary tract from the major cause of morbidity and mortality in these patients, the renal function deterioration caused by hydronephrosis and pyelonephritis. ${ }^{4}$

Today, the standard treatment for neurogenic hyperreflexic bladders consists of clean intermittent catheterization combined with anticholinergic medica-

*Correspondence: A Haferkamp, Department of Urology, University of Heidelberg Im Neuenheimer Feld 110, 69120 Heidelberg, Germany.

This paper was presented in part at the World Endourology Congress in New York in September 1998 tion. Intermittent catheterization increases the effective bladder capacity by decreasing the residual urine and prevents high voiding pressures. Anticholinergics provide a bladder acting as a low pressure urinary reservoir and prevent urinary incontinence by relaxation of the hyperreflexic detrusor. ${ }^{5}$ Of the anticholinergic agents that are currently available oxybutynin hydrochloride is most commonly used. It is a tertiary amine with neurotropic especially antimuscarinic and anticholinergic as well as myotropic, antispasmodic and local anesthetic action. ${ }^{6}$

The clinical efficacy of oral oxybutynin in the treatment of detrusor hyperreflexia is demonstrated in several randomized, controlled, double-blind trials. Moisey et $a l^{7}$ for example found an improvement of symptoms in $69 \%$ of their patients. In a randomized double-blind multi-center trial Thüroff et $a l^{8}$ found a significantly higher grade of improvement with 
oxybutynin (about 58\%) than with propantheline (about 44\%) and placebo (43\%).

Several side effects have been described with oral oxybutynin: dryness of the mouth, constipation, diarrhea, cardiac arrhythmias, vision disturbances, gastric distress, nausea, headache, hot flushes, tinnitus and fatigue.

A different form of application, the intravesical application of oxybutynin is used in neurogenic bladder patients who remain incontinent on oral anticholinergic medication or do not tolerate this oral medication due to the side effects described before. 6,9

In most reports intravesical oxybutynin is used in dosages between 0.2 and $0.4 \mathrm{mg} / \mathrm{kg}$ bodyweight per day. ${ }^{5,10}$ To the best of our knowledge no higher dosages have been reported in the literature. However, the efficacy of this therapy and the side effects remain unclear in the literature. Brendler et $a l^{6}$ and Greenfield et $a l^{11}$ found an improvement in continence rate in more than $80 \%$ of their patients and no side effects of the intravesical therapy. Kaplinsky et $a l^{12}$ could only find an improvement in continence rate in $61 \%$ of their patients and found intolerable side effects in $25 \%$ of their patients. Therefore the aim of our prospective analysis was to evaluate the efficacy and the side effects of a standard dosage of intravesical oxybutynin $(0.3 \mathrm{mg} / \mathrm{kg}$ bodyweight per day) and the effects of an increasing intravesical dosage $(0.5$ to $0.9 \mathrm{mg} / \mathrm{kg}$ bodyweight per day) in neurogenic hyperreflexic bladder patients.

\section{Materials and methods}

\section{Inclusion criteria}

All patients included in this cohort study had to have neurogenic bladders with detrusor hyperreflexia. Indications for intravesical therapy included inadequate therapeutic response on oral anticholinergic medication ( $n=15$ patients) and/or intolerable side effects from the oral formulation ( $n=13$ patients), and difficulty in swallowing of the oxybutynin tablets in young children $(n=4$ patients).

\section{Exclusion criteria}

All patients with the suspicion of external sphincter insufficiency and an abdominal leak point pressure less than $40 \mathrm{~cm} \mathrm{H}_{2} \mathrm{O}$ were excluded from the study. Patients with oral anticholinergic, antispasmodic and sympathomimetic medication were also excluded.

\section{Aim of treatment}

The primary goal of treatment was to achieve continence during day and night time. A secondary goal was videourodynamically proven success criteria, defined as:

(1) age adjusted bladder capacity greater than $70 \%$
(2) compliance $15 \mathrm{ml} / \mathrm{cmH}_{2} \mathrm{O}$ or more

(3) maximal detrusor pressure less than $40 \mathrm{cmH}_{2} \mathrm{O}$

\section{Trial protocol}

All patients performed intermittent catheterization five times daily. They all had a pre-treatment videourodynamic evaluation. Treatment started with a standard dosage (A) of $0.3 \mathrm{mg} / \mathrm{kg}$ bodyweight per day $(0.3 \mathrm{mg} /$ $\mathrm{kg} \mathrm{BWd}$ ), divided into three portions instilled every $8 \mathrm{~h}$. Videourodynamic studies were repeated $2-4$ weeks after beginning of intravesical oxybutynin therapy. In patients where the dosage (A) failed to reach total continence and treatment success criteria the dosage (B) was increased in steps of $0.2 \mathrm{mg} / \mathrm{kg}$ bodyweight per day up to a maximum dosage of $0.9 \mathrm{mg} / \mathrm{kg}$ bodyweight per day if necessary. Two to four weeks after each dosage increase, treatment effect was evaluated videourodynamically. Dosage increase was stopped when continence and treatment success criteria were reached.

For the intravesical application, commercially available $5 \mathrm{mg}$ oxybutynin powder was dissolved in $15 \mathrm{ml}$ sterile isotonic sodium chloride solution. The dose of the solution, adjusted to the patients' bodyweight, was instilled into the bladder through the catheter used for regular intermittent catheterization. The catheter was then flushed with $5 \mathrm{ml}$ isotone sodium chloride solution to ensure delivery of the full dose and it was removed afterwards. The solution remained intravesically until the bladder was next emptied by catheterization.

Patients or parents maintained a detailed sheet of drug administration, of incontinence periods, of side effects during intravesical therapy and urine output by volume charts.

Videourodynamic studies were performed according to ICS criteria. ${ }^{13}$ All studies were done in the mornings after the first intravesical application with the oxybutynin in the bladder until the beginning of the videourodynamic evaluation. A MMS 2000 urodynamic system (Innocept ${ }^{\circledR}$, Gladbeck, Germany) was used with the patient in supine position. Radiopaque material $\left(37^{\circ} \mathrm{C}\right)$ was infused into the bladder through a $6 \mathrm{~F}$ or $9 \mathrm{~F}$ double lumen urethral catheter (Rüsch ${ }^{\circledR}$, Böblingen, Germany). A $6 \mathrm{~F}$ catheter was used in patients up to 10 years of age, a $9 \mathrm{~F}$ catheter in patients older than 10 years. The infusion rate was between 2 and $20 \mathrm{ml} / \mathrm{min}$ depending on the patients age. The bladder filling was stopped when the age expected bladder capacity was reached to avoid bladder overdistension. Maximal detrusor pressure, total bladder capacity and detrusor compliance were evaluated.

\section{Included patients}

Since 1995, 32 incontinent patients with neurogenic hyperreflexic bladders, 18 male and 14 female with a mean age of 12 years (range $1-34$ years), were 
treated with intravesical application of oxybutynin at our department. They consist of 10 tetraplegic and 22 paraplegic patients. Seventeen patients had a spinal cord injury, and 15 were meningomyelocele patients.

\section{Definitions and statistical analysis}

The total bladder capacity evaluated by videourodynamic study is dependent on age. A comparison of capacities of patients with different ages is only possible, when an age independent value can be defined. Therefore we defined the age adjusted capacity using the formula: Age adjusted capacity $=($ actual videourodynamic capacity/age expected capacity) $\times 100$. According to Berger and associates the age expected capacity was calculated for patients of less than 12 years using the formula: Age expected capacity $=($ age in years +2$) \times 30 \mathrm{ml}^{14}$ For patients over 12 years of age, expected capacity was estimated at $500 \mathrm{ml}$.
Statistical analysis was performed on all data using the Wilcoxon range sum test. ${ }^{15}$ The level of significance was preset to $P<0.05$. Statistical software was used: Statistical Analysing System (SAS), Version $6.04 .^{16}$

\section{Results}

Thirty-two patients with neurogenic bladders were treated with intravesical oxybutynin. A summary of our patients' data is shown in Tables 1-4.

\section{Continence}

Without anticholinergic medication all 32 patients were incontinent during the day and night-time. All patients used diapers. Using intravesical oxybutynin in a standard dosage (A), 21 patients became totally continent. The remaining 11 patients were incontinent, nine during the day and night-time, and two only during night-time. Using increased dosage titration (B)

Table 1 Patients' age, cause of neurogenic bladder dysfunction and response to different oxybutylin dosages

\begin{tabular}{|c|c|c|c|c|c|}
\hline $\begin{array}{l}\text { Patients, } \\
\text { age } \\
\text { [years] }\end{array}$ & $\begin{array}{l}\text { Cause of } \\
\text { neurogenic bladder } \\
\text { dysfunction }\end{array}$ & $\begin{array}{l}\text { (In-) continence } \\
\text { using a daily dosage } \\
\text { of oxybutynin: } \\
0.3 \mathrm{mg} / \mathrm{kg} \mathrm{BW}\end{array}$ & $\begin{array}{l}\text { (In-) continence } \\
\text { using a daily dosage } \\
\text { of oxybutynin: } \\
0.5 \mathrm{mg} / \mathrm{kg} \mathrm{BW}\end{array}$ & $\begin{array}{l}\text { (In-) continence } \\
\text { using a daily dosage } \\
\text { of oxybutynin: } \\
0.7 \mathrm{mg} / \mathrm{kg} \mathrm{BW}\end{array}$ & $\begin{array}{l}\text { (In-) continence } \\
\text { using a daily dosage } \\
\text { of oxybutynin: } \\
0.9 \mathrm{mg} / \mathrm{kg} \mathrm{BW}\end{array}$ \\
\hline 1 & $\mathrm{mmc}$ & continent & & & \\
\hline 3 & $\mathrm{mmc}$ & continent & & & \\
\hline 3 & $\mathrm{mmc}$ & continent & & & \\
\hline 4 & sci & incontinent & continent & & \\
\hline 5 & $\mathrm{mmc}$ & incontinent & incontinent & continent & \\
\hline 6 & sci & continent & & & \\
\hline 6 & sci & continent & & & \\
\hline 7 & $\mathrm{mmc}$ & continent & & & \\
\hline 7 & $\mathrm{mmc}$ & incontinent & incontinent & continent & \\
\hline 7 & $\mathrm{mmc}$ & incontinent & incontinent & incontinent & incontinent \\
\hline 8 & $\mathrm{mmc}$ & continent & & & \\
\hline 8 & $\mathrm{mmc}$ & continent & & & \\
\hline 9 & $\mathrm{mmc}$ & incontinent & continent & & \\
\hline 9 & sci & continent & & & \\
\hline 10 & sci & continent & & & \\
\hline 11 & sci & incontinent & incontinent & continent & \\
\hline 11 & $\mathrm{mmc}$ & incontinent & incontinent & incontinent & incontinent \\
\hline 12 & $\mathrm{mmc}$ & continent & & & \\
\hline 12 & $\mathrm{mmc}$ & continent & & & \\
\hline 14 & sci & incontinent & incontinent & incontinent & continent \\
\hline 14 & sci & continent & & & \\
\hline 14 & $\mathrm{mmc}$ & continent & & & \\
\hline 16 & sci & incontinent & incontinent & incontinent & incontinent \\
\hline 17 & sci & continent & & & \\
\hline 17 & sci & incontinent & incontinent & incontinent & incontinent \\
\hline 18 & sci & continent & & & \\
\hline 18 & sci & continent & & & \\
\hline 19 & sci & continent & & & \\
\hline 19 & $\mathrm{mmc}$ & continent & & & \\
\hline 22 & sci & continent & & & \\
\hline 23 & sci & continent & & & \\
\hline 34 & sci & incontinent & incontinent & continent & \\
\hline
\end{tabular}

$\mathrm{mmc}=$ meningomyelocele; $\mathrm{sci}=$ spinal cord injury 
Table 2 Videourodynamic changes with different intravesical dosages of oxybutynin: (median and range)

\begin{tabular}{|c|c|c|c|}
\hline $\begin{array}{l}\text { Oxybutynin dosage } \\
{[\mathrm{mg} / \mathrm{kg} \mathrm{BW} d]}\end{array}$ & $\begin{array}{c}\text { Age adjusted bladder } \\
\text { capacity }[\%]\end{array}$ & Compliance $\left[\mathrm{ml} / \mathrm{cmH}_{2} \mathrm{O}\right]$ & $\begin{array}{c}\text { Maximal detrusor pressure } \\
{\left[\mathrm{CmH}_{2} \mathrm{O}\right]}\end{array}$ \\
\hline $\begin{array}{l}\text { No oxybutynin } \\
\quad(n=32 \text { patients })\end{array}$ & $39.4[16-70]$ & $7.5[2-20]$ & $98[50-140]$ \\
\hline $\begin{array}{l}0.3 \\
\quad(n=32 \text { patients })\end{array}$ & $76.8[31-100]$ & $18.5[2-27]$ & $35[15-114]$ \\
\hline $\begin{array}{l}0.5 \text { to } 0.9 \\
\quad(n=11 \text { patients })\end{array}$ & $85.6[52-100]$ & $27.1[7-47]$ & $32[10-83]$ \\
\hline
\end{tabular}

Table 3 Videourodynamic data and continence situation with intravesical application of oxybutynin (dosage $0.3 \mathrm{mg} / \mathrm{kg}$ BWd)

\begin{tabular}{lcc}
\hline & $\begin{array}{c}\text { Continence } \\
(\mathrm{n}=21 \text { patients })\end{array}$ & $\begin{array}{c}\text { Incontinence } \\
(\mathrm{n}=11 \text { patients })\end{array}$ \\
\hline $\begin{array}{c}\text { Median age adjusted } \\
\text { bladder capacity } \\
\text { (per cent) }\end{array}$ & 83.0 & 45.4 \\
$\begin{array}{c}\text { Median compliance } \\
\left(\mathrm{ml} / \mathrm{cmH}_{2} \mathrm{O}\right)\end{array}$ & 22.0 & 7.7 \\
$\begin{array}{c}\text { Median } \max \text { detrusor } \\
\text { pressure }\left(\mathrm{cmH}_{2} \mathrm{O}\right)\end{array}$ & 24 & 96 \\
\hline
\end{tabular}

up to maximal $0.9 \mathrm{mg} / \mathrm{kg}$ bodyweight per day, seven of these 11 patients became totally continent, four patients remained incontinent during the day and night-time. The median increased dosage to achieve total continence in these seven patients was $0.7 \mathrm{mg} / \mathrm{kg}$ bodyweight per day.

\section{Videourodynamic data}

Without anticholinergic medication the median age adjusted bladder capacity and the median compliance was reduced, the median maximal detrusor pressure was increased. Median age adjusted bladder capacity and median compliance could be increased significantly $(P<0.01)$, median maximal detrusor pressure could be decreased significantly $(P<0.01)$ using a standard dosage of intravesical oxybutynin (A). Dividing the patients in a group who became totally continent using the standard dosage (A) and in a group with persisting incontinence we obtained the following results: the 21 continent patients fulfilled all treatment success criteria, the 11 patients who remained incontinent on dosage (A) showed nearly no change in median age adjusted bladder capacity, median compliance and median maximal detrusor pressure. These 11 patients were treated with the increased dosage titration (B). An additional significant increase $(P<0.05)$ of median age adjusted bladder capacity and median compliance and a significant decrease $(P<0.05)$ of median maximal detrusor pressure could be achieved. Dividing these 11 patients into a group who became totally continent using the dosage escalation (B) and a group with persisting incontinence we obtained the following
Table 4 Videourodynamic data and continence situation with intravesical application of oxybutynin (dosage $0.5 \mathrm{mg} / \mathrm{kg}$ BWd to $0.9 \mathrm{mg} / \mathrm{kg} \mathrm{BWd}$ )

\begin{tabular}{lcc}
\hline & $\begin{array}{c}\text { Continence } \\
(\mathrm{n}=7 \text { patients })\end{array}$ & $\begin{array}{c}\text { Incontinence } \\
(\mathrm{n}=4 \text { patients })\end{array}$ \\
\hline $\begin{array}{c}\text { Median age adjusted } \\
\text { bladder capacity } \\
\text { (per cent) }\end{array}$ & 96.0 & 67.3 \\
$\begin{array}{c}\text { Median compliance } \\
\left(\mathrm{ml} / \mathrm{cmH}_{2} \mathrm{O}\right)\end{array}$ & 38.0 & 8.0 \\
$\begin{array}{c}\text { Median max detrusor } \\
\text { pressure }\left(\mathrm{cmH}_{2} \mathrm{O}\right)\end{array}$ & 23 & 70 \\
\hline
\end{tabular}

results: seven continent patients reached all treatment success criteria and four incontinent patients showed a slight increase in median age adjusted bladder capacity and median compliance and a slight decrease of median maximal detrusor pressure, but did not reach the predefined treatment success criteria. These four patients underwent surgery. Three patients underwent ileocystoplasty and one patient underwent external sphincterotomy.

In five out of seven patients, who had been successfully treated with escalating dosage titration (B), a complete follow up of at least 12 months was available. They remained continent and continued to fulfil our predefined success criteria. None of these patients had any local bladder problems, especially no stone formation.

\section{Side-effects}

No patient complained of any side-effects using the intravesical application of oxybutynin in the standard dosage (A). Using escalating dosage titration (B) two of the 11 patients complained of constipation and dryness of the mouth at a dosage of $0.9 \mathrm{mg} / \mathrm{kg}$ bodyweight per day. No intravesical oxybutynin treatment had to be stopped due to side-effects.

\section{Discussion}

The pharmacokinetics of oxybutynin chloride have not been sufficiently delineated to explain the mechanism responsible for the effects after intravesical administration: Massad et $a l^{17}$ measured plasma oxybutynin 
chloride levels in children after oral and intravesical administration and demonstrated higher levels but fewer complications after intravesical administration. Side-effects only occurred in children who underwent enterocystoplasty. On the other hand Madersbacher et $a l^{9}$ found that peak plasma levels of intravesical oxybutynin appear later, are lower and stay longer compared to oral intake. In addition Amark et al ${ }^{18}$ could not demonstrate a clear relationship between minimal plasma levels of oxybutynin and its clinical effects.

In our study, we did not measure oxybutynin plasma levels due to limited departmental funding. We focused on clinical factors such as continence situation, efficacy and side-effects of therapy. Considering side effects, Massad et al $^{17}$ and Madersbacher et $a l^{9}$ described a lack of significant side effects after intravesical application of oxybutynin. Greenfield et $a l,{ }^{11}$ Brendler et $a l^{6}$ and Prasad et al ${ }^{19}$ also reported no side effects. This is in contrast to Palmer et $a l^{20}$ who described severe side-effects, leading to cessation of therapy, in at least $26 \%$ of their patients using a standard dosage of intravesical oxybutynin. Kaplinsky et $a l^{12}$ described $25 \%$ intolerable side-effects in their meningomyelocele patients using a standard dosage of intravesical oxybutynin.

In our study we found no side-effects with the standard dosage (A). Only two of our 11 patients $(18 \%)$ showed slight side-effects using the highest dosage escalation (B). Since, to the best of our knowledge, there is no other study in the literature using an equivalent dosage escalation of oxybutynin a comparison of side-effects is not possible. Our results suggest that side effects are rare even using a dosage escalation of oxybutynin. Continence rates achieved by intravesical oxybutynin therapy are discussed controversially in the literature. Buyse et $a l^{5}$ reported day and night time continence in all patients, whereas Kaplinsky et $a l^{12}$ found persistence of incontinence in $43 \%$ of their patients. We found day and night-time continence in $66 \%$ of our patients using a standard oxybutynin dosage (A) and in $87 \%$ of patients including the escalating dosage titration (B). Therefore we assume that there is a number of patients where the continence situation can be improved significantly using a dosage escalation of intravesical oxybutynin.

In our study we describe an significant improvement in urodynamic data such as age adjusted bladder capacity, maximal detrusor pressure and compliance, which is in accordance with several reports in the literature. ${ }^{5-7,9,11,12,18,19,21}$

Prasad et $a l^{19}$ found an overall improvement in $88 \%$ of their patients using a standard oxybutynin dosage. In our study, an improvement rate of $87 \%$ could only be achieved using dosage escalation (B). Palmer et $a l^{20}$ found that only $35 \%$ of their patients improved by the therapy.

In conclusion the intravesical application of oxybutynin is a well tolerated and efficacious therapy. The topical oxybutynin therapy using a standard dosage $(0.3 \mathrm{mg} / \mathrm{kg} \mathrm{BWd})$ was efficient in $66 \%$ of our selected patients, very high dosages (up to $0.9 \mathrm{mg} / \mathrm{kg} \mathrm{BWd}$ ) can increase the efficiency to $87 \%$ without intoxicity and slight side-effects.

\section{References}

1 Guttmann L, Frankel H. The value of intermittent catheterization in the early management of traumatic paraplegia and tetraplegia. Paraplegia 1966; 4: $63-84$.

2 Lapides J, Diokno AC, Silber SJ, Lowe BS. Clean, intermittent self-catheterization in the treatment of urinary tract disease. $J$ Urol 1972; 107: 458

3 McGuire EJ, Woodside JR, Borden TA, Weiss RM. Prognostic value of urodynamic testing in myelodysplastic patients. J Urol 1981; 126: 205.

4 Spindel MR et al. The changing neurourologic lesion in myelodysplasia. JAMA 1987; 258: 1630.

5 Buyse G, Verpoorten C, Vereecken R, Casaer P. Treatment of neurogenic bladder dysfunction in infants and children with neurospinal dysraphism with clean intermittent catheterization and optimized intravesical Oxybutynin hydrochloride therapy. Eur J Ped Surg 1985; 5 (Suppl.1) 31-34.

6 Brendler CB, Radebaugh LC, Mohler JL. Topical oxybutynin chloride for relaxation of dysfunctional bladders. J Urol 1989; 141: $1350-1351$

7 Moisey CU, Stephenson TP, Brendler CB. The urodynamic and subjective results of treatment of detrusor instability with oxybutynin chloride. Brit J Urol 1980; 52: 472.

8 Thüroff JW et al. Randomized, double-blind, multicenter trial on treatment of frequency, urgency and incontinence related to detrusor hyperactivity. Oxybutynin versus propantheline versus placebo. J Urol 1991; 145: 813-817.

9 Madersbacher H, Knoll M. Intravesical application of Oxybutynin. Mode of action in controlling detrusor hyperreflexia. Eur Urol 1995; 28: 340 - 344 .

10 Autret E et al. Plasma levels of oxybutynin chloride in children. Eur J Clin Pharmacol 1994; 46: $83-85$.

11 Greenfield SP, Fera M. The use of intravesical Oxybutynin chloride in children with neurogenic bladder. J Urol 1991; 146: $532-534$.

12 Kaplinsky R, Greenfield S, Wan J, Fera M. Expanded follow up of intravesical Oxybutynin chloride use in children with neurogenic bladder. J Urol 1996; 156: $753-756$.

13 Abrams P, Blaivas JG, Stanton SL, Anderson JT. The standardisation of teminology of lower urinary tract function. Scand J Urol Nephrol 1988; 114: 5- 19.

14 Berger RM et al. Bladder capacity (ounces) equals age (years) plus 2 predicts normal bladder capacity and aids in diagnosis of abnormal voiding patterns. J Urol 1983; 129: 347.

15 Köhler W, Schachtel G, Voleske P. Eine Auswahl wichtiger Tests. In: Biostatistik. 2nd edn, p103, Springer Heidelberg: Germany, 1995.

16 SAS Procedure Guide. Version 6, 3rd edn, Cary: NC, 1990

17 Massad CA, Kogan BA, Trigo-Rocha FE. The pharmacokinetics of intravesical and oral oxybutynin chloride. J Urol 1992; 148: $595-597$

18 Amark P et al. Pharmacokinetics and effects of intravesical Oxybutynin on the paediatric neurogenic bladder. $\mathrm{Br} \mathrm{J}$ Urol 1998; 82: $859-864$.

19 Prasad KVR, Vaidyanathan S. Intravesical Oxybutynin chloride and clean intermittent catherization in patients with neurogenic vesical dysfunction and decreased bladder capacity. Br J Urol 1993; 72: 719-722.

20 Palmer LS, Zebold K, Firlit CF, Kaplan WE. Complications of intravesical Oxybutynin chloride therapy in the pediatric myelomeningocele population. J Urol 1997; 157: 638-640.

21 Mizunaga $\mathbf{M}$ et al. Intravesical instillation of Oxybutynin hydrochloride, therapy for patients with a neuropathic bladder. Paraplegia 1994; 342: $25-29$. 